\title{
VALIDITAS KETERANGAN AHLI DARI PENYIDIK DALAM PEMBUKTIAN KASUS UJARAN KEBENCIAN RAS DI MEDIA SOSIAL (STUDI PUTUSAN: NO.1105/PID.SUS/2017/PN JKT.UTR)
}

\author{
Hendra \\ (Mahasiswa Program S1 Fakultas Hukum Universitas Tarumanagara) \\ (E-mail: hendralun08@gmail.com)
}

\section{Dian Andriawan Daeng Tawang}

(Corresponding Author)

(Dosen Hukum Pidana Fakultas Hukum Universitas Tarumanagara, Meraih Sarjana Hukum dari

Fakultas Hukum Universitas Hasanuddin Makassar, Magister Hukum dari Fakultas Hukum Universitas

Hasanuddin Makassar, Doktor Hukum dari Fakultas Hukum Universitas Hasanuddin Makassar)

(E-mail: dian.adriawan@gmail.com)

\begin{abstract}
Expert's Testimony is the information of a person who has special expertise for the purpose of examination in a criminal case and must be given in court. An expert must provide information for justice, as well as possible and according to knowledge in his area of expertise. The expert's testimony from the police is still questionable on the independence and justice of the defendant, the expert must be independent and fair in giving explanation there should be no influence from internal or external parties. There are still many expert testimonies from investigators who are highly doubtful of their independence and deemed inappropriate to be made expertly by academicians, but in the Criminal Procedure Code it is not clear whether the expert's testimony from the investigator is allowed or not. Therefore the author interested in conducting research related to the validity of expert testimony from investigators. The author conducted research with normative legal research methods supported by interviews are expected to help answer the research and the source of interviewed is from the academics and practitioners. In the absence of clear rules, the expert's testimony from the investigator will be the pros and cons but if it refers to the understanding and the main purpose of expert testimony in the Criminal Procedure Code, it is unlikely that the expert's expertise is allowed because it will not be free, independent.

Keywords: Expert Testimony, Investigator.
\end{abstract}




\section{PENDAHULUAN}

\section{A. Latar Belakang}

Indonesia adalah negara yang berdasarkan atas hukum, maka kehidupan masyarakat tidak lepas dari aturan hukum. Pasal 1 Ayat (3) Undang-Undang Dasar Negara Republik Indonesia Tahun 1945 secara jelas menegaskan bahwa Negara Indonesia adalah negara yang berdasarkan hukum (rechstaat), tidak berdasarkan atas kekuasaan belaka (machtstaat). Hukum pada dasarnya adalah sesuatu yang abstrak sehingga menimbulkan persepsi yang berbeda-beda tentang definisi hukum, tergantung dari sudut mana mereka memandangnya. ${ }^{1)}$

Menurut Achmad Ali, hukum adalah seperangkat kaidah atau ukuran yang tersusun dalam suatu sistem yang menentukan apa yang boleh dan tidak boleh dilakukan manusia sebagai warga negara dalam kehidupan bermasyarakat. Hukum tersebut bersumber baik dari masyarakat sendiri maupun dari sumber lain yang diakui berlakunya oleh otoritas tertinggi dalam masyarakat tersebut, serta benar-benar diberlakukan oleh warga masyarakat sebagai satu keseluruhan dalam kehidupannya. Apabila kaidah tersebut dilanggar akan memberikan kewenangan bagi otoritas tertinggi untuk menjatuhkan sanksi yang sifatnya eksternal. ${ }^{2)}$

Berbagai fokus pembahasan ilmu hukum, salah satu dari kajian ilmu hukum yang sangat penting adalah kajian ilmu hukum pidana. Hukum pidana adalah sejumlah peraturan yang merupakan bagian dari hukum positif yang mengandung larangan-larangan dan keharusan-keharusan yang ditentukan oleh negara atau kekuasaan lain yang berwenang untuk menentukan peraturan pidana. Larangan atau keharusan itu disertai ancaman pidana dan apabila hal ini dilanggar timbullah hak, negara untuk melakukan tuntutan, menjatuhkan pidana, melaksanakan pidana. ${ }^{3)}$

Adapun yang dimaksud dengan hukum pidana materiil atau Kitab UndangUndang Hukum Pidana berisi petunjuk dan uraian tentang delik, peraturan tentang

\footnotetext{
1) Achmad Ali, Menguak Tabir Hukum. (Jakarta: PT Ghalia Indonesia, 2008), hal. 11.

2) Ibid., hal. 30 .

3) Amir Ilyas, Asas-Asas Hukum Pidana. (Yogyakarta: Rangkang Education Yogyakarta \& Pu-Kap Indonesia, 2012), hal. 3.
} 
syarat-syarat dapat tidaknya orang dipidana dan aturan tentang pemidanaan, yaitu mengatur kepada siapa dan bagaimana pidana itu dijatuhkan, sedangkan hukum pidana formil atau Kitab Undang-Undang Hukum Acara Pidana mengatur bagaimana negara melalui alat-alatnya melaksanakan haknya untuk memidana dan menjatuhkan pidana, jadi berisi acara pidana. Jadi dapat disimpulkan bahwa hukum pidana materiil adal hukum yang berisikan materi hukuman, sedangkan hukum pidana formil adalah hukum yang mengatur tentang tata cara bagaimana melaksanakan hukum materiil tersebut. $^{4)}$

Peradilan pidana pada hakikatnya merupakan suatu sistem kekuasaan penegakkan hukum pidana atau sistem kekuasaan kehakiman di bidang hukum pidana yang diwujudkan atau diimplementasikan dalam 4 (empat) subsistem yaitu: Kekuasaan penyidikian (oleh badan/ lembaga penyidik); Kekuasaan penuntutan (oleh badan/ lembaga penuntut umum); Kekuasaan mengadili dan menjatuhkan pidana (oleh badan pengadilan); dan Kekuasaan pelaksanaan pidana (oleh badan aparat pelaksana/ eksekusi). Keempat tahap/ subsistem tersebut merupakan satu kesatuan sistem penegakan hukum pidana yang integral atau sering dikenal dengan istilah sistem peradilan pidana terpadu (integrated criminal justice system). Sistem terpadu tersebut diletakkan di atas landasan undang-undang kepada masing-masing. ${ }^{5)}$

Pembuktian adalah ketentuan-ketentuan yang berisi penggarisan dan pedoman tentang tata cara yang dibenarkan undang-undang membuktikan kesalahan yang didakwakan kepada terdakwa. Pembuktian juga merupakan ketentuan yang mengatur mengenai alat-alat bukti yang dibenarkan undang-undang dan mengatur mengenai alat bukti yang boleh digunakan hakim guna membuktikan kesalahan terdakwa. ${ }^{6}$

Alat-alat bukti dalam KUHAP memegang peranan yang sangat penting dalam proses pembuktian karena sebagai dasar bagi hakim menjatuhkan putusan terhadap

\footnotetext{
4) Andi Sofyan dan H. Abd. Asis, Hukum Acara Pidana Suatu Pengantar, (Jakarta: Prenadamedia Group, 2014), hal. 2.

5) M. Yahya Harahap, Pembahasan Permasalahan dan Penerapan KUHAP: Penyidikan dan Penuntutan. (Jakarta: Sinar Grafika, 2010), hal. 90.

${ }^{6)}$ Eddy O.S. Hiariej, Teori \& Hukum Pembuktian. (Jakarta: Penerbit Erlangga, 2012), hal. 4.
} 
terdakwa, baik menyatakan terdakwa bersalah maupun menyatakan terdakwa tidak bersalah. Alat-alat bukti ini juga dipergunakan sebagai bahan pembuktian. Alat bukti dalam pidana diatur dalam Pasal 184 Ayat (1) KUHAP yaitu:

1. Keterangan saksi;

2. Keterangan ahli;

3. Surat;

4. Petunjuk;

5. Keterangan terdakwa.

Pasal 1 angka 28 keterangan ahli adalah keterangan yang diberikan oleh seorang yang memiliki keahlian khusus tentang hal yang diperlukan untuk membuat terang suatu perkara pidana guna kepentingan pemeriksaan.

Keterangan ahli yang diatur dalam KUHAP dirasa belum cukup mengatur karena masih ada keterangan ahli yang belum diatur secara eksplisit dalam KUHAP maupun peraturan perundang-undangan yang lain tetapi sudah digunakan dalam praktik beracara pidana di Indonesia yakni keterangan ahli dari penyidik.

Menurut KUHAP, Penyidik adalah pejabat polisi negara Republik Indonesia atau pejabat pegawai negeri sipil tertentu yang diberi wewenang khusus oleh undangundang untuk melakukan penyidikan.

Seiring dengan perkembangan jaman dan teknologi banyak kejahatan yang pada semulanya hanya kejahatan di dunia nyata hingga adanya kejahatan di dunia maya (kejahatan mayantara). Salah satu kejahatan di dunia maya yang sering kita temukan adalah kejahatan ujaran kebencian ras di media sosial.

Larangan ujaran kebencian ras di media sosial telah diatur dalam UndangUndang No.19 Tahun 2016 tentang Perubahan Atas Undang-Undang No.11 Tahun 2008 tentang Informasi dan Transaksi Elektronik Pasal 28 Ayat (2) yang menyatakan:

"Setiap Orang dengan sengaja dan tanpa hak menyebarkan informasi yang ditujukan untuk menimbulkan rasa kebencian atau permusuhan individu dan/atau kelompok masyarakat tertentu berdasarkan atas suku, agama, ras, dan antargolongan (SARA)”.

Contoh penerapannya adalah apabila seseorang menuliskan status dalam jejaring sosial informasi yang berisi provokasi terhadap suku/agama tertentu dengan 
maksud menghasut masyarakat untuk membenci atau melakukan anarki terhadap kelompok tertentu, maka Pasal 28 Ayat (2) UU ITE ini secara langsung dapat dipergunakan oleh Aparat penegak Hukum (“APH”) untuk menjerat pelaku yang menuliskan status tersebut. ${ }^{7)}$

Larangan ujaran kebencian Ras selain diatur dalam UU ITE, secara eksplisit diatur juga dalam Undang-Undang No.40 Tahun 2008 tentang Penghapusan Diskriminasi Ras dan Etnis. Dalam Pasal 4 UU No.40 Tahun 2008 tentang Penghapusan Diskriminasi Ras dan etnis telah jelas melarang orang menunjukkan kebencian arau rasa benci kepada orang lain karena perbedaan ras dan etnis.

Penelitian ini bertolak dari penggunaan keterangan ahli dari penyidik dalam proses perkara pidana, dengan objek dari penelitian ini adalah pernyataan dari keterangan ahli dari penyidik dalam proses pemeriksaan di pengadilan dalam kasus putusan No. 1105/Pid.Sus/2017/PN Jkt.Utr yang merupakan kasus ujaran kebencian ras dalam media sosial oleh Muhammad Faizal Tanong P, dimana salah satu keterangan ahli yang dihadirkan dalam sidang pengadilan ialah keterangan ahli dari penyidik.

Selanjutnya, pembahasan penelitian ini akan menjelaskan bagaimana validitas pembuktian keterangan ahli dari penyidik, seperti diketahui bahwa alat bukti elektronik diproses oleh pihak penyidik dan penyidik dari institusi yang sama menjadi ahli dalam perkara tersebut.

Berdasarkan hal yang telah diuraikan di atas maka penulis tertarik untuk menyusun jurnal dengan mengangkat judul "VALIDITAS KETERANGAN AHLI DARI PENYIDIK DALAM PEMBUKTIAN KASUS UJARAN KEBENCIAN RAS DI MEDIA SOSIAL (STUDI PUTUSAN: NO. 1105/PID.SUS/2017/PN JKT.UTR)"•

\footnotetext{
7) Joshua Sitompul, "Pasal Untuk Menjerat Penyebar Kebencian SARA Di Jejaring Sosial", www.hukumonline.com, 16 Januari 2018, hal.1.
} 


\section{B. Permasalahan}

Berdasarkan uraian latar belakang yang telah penulis uraikan adapun permasalahan yang akan dibahas adalah:

Bagaimana validitas keterangan ahli dari penyidik dalam kasus ujaran kebencian ras di media sosial putusan No.1105/Pid.Sus/2017/PN Jkt.Utr?

\section{Metode Penelitian}

Penelitian hukum merupakan suatu kegiatan know-how dalam ilmu hukum, bukan sekedar know-about. Sebagai kegiatan know-how, penelitian hukum dilakukan untuk memecahkan isu hukum yang dihadapi. Di sinilah dibutuhkan kemampuan untuk mengidentifikasi masalah hukum, melakukan penalaran hukum, menganalisis masalah yang dihadapi dan kemudian memberikan pemecahan atas masalah tersebut. ${ }^{8)}$ Demikian dalam penelitian ini Penulis akan menentukan metode-metode yang akan digunakan, yakni sebagai berikut:

\section{Jenis Penelitian}

Jenis penelitian yang akan digunakan oleh Penulis dalam penelitian ini adalah penelitian hukum normatif atau doktrinal. Penelitian hukum normatif atau doktrinal adalah penelitian yang memberikan penjelasan sistematis aturan yang mengatur suatu kategori hukum tertentu, menganalisis hubungan antara peraturan menjelaskan daerah kesulitan dan mungkin memprediksi pembangunan masa depan. ${ }^{9)}$

\section{Pendekatan}

Dalam penelitian ini Penulis akan menggunakan pendekatan konseptual. Pendekatan konseptual beranjak dari pandangan-pandangan dan doktrin-doktrin yang

\footnotetext{
${ }^{8)}$ Peter Mahmud Marzuki, Penelitian Hukum, Edisi Revisi. (Jakarta: Kencana Prenadamedia Group, 2009), hal. 60.

9) Peter Mahmud Marzuki, Penelitian Hukum, Cetakan ke-7. (Jakarta: Kencana Prenada Media Group, 2011), hal. 35.
} 
berkembang di dalam ilmu hukum. Dengan mempelajari pandangan-pandangan dan doktrin-doktrin di dalam ilmu hukum, peneliti akan menemukan ide-ide yang melahirkan pengertian-pengertian hukum, konsep-konsep hukum, dan asas-asas hukum yang relevan dengan isu yang dihadapi. Pemahaman akan pandanganpandangan dan doktrin-doktrin tersebut merupakan sandaran bagi peneliti dalam membangun suatu argumentasi hukum dalam memcahkan isu yang dihadapi. ${ }^{10)}$ Pendekatan konseptual dilakukan manakala peneliti tidak beranjak dari aturan hukum yang ada. Hal itu dilakukan karena memang belum atau tidak ada aturan hukum untuk masalah yang dihadapi. ${ }^{11)}$

\section{Jenis Bahan Hukum}

Penulis akan menggunakan jenis bahan hukum dalam penelitian ini adalah sebagai berikut:

a. Bahan Hukum

1) Bahan hukum primer merupakan bahan hukum yang bersifat autoritatif, artinya mempunyai otoritas. Bahan hukum primer terdiri dari perundang-undangan, catatan-catatan resmi atau risalah dalam pembuatan perundang-undangan dan putusan-putusan hakim. ${ }^{12)}$ Maka dari itu Penulis dalam penelitian ini akan merujuk pada Undang-Undang Dasar NRI 1945, Undang-Undang No.8 Tahun 1981 tentang Hukum Acara Pidana (KUHAP), Undang-Undang No.19 Tahun 2016 tentang Perubahan Atas Undang-Undang Nomor 11 Tahun 2008 tentang Informasi dan Transaksi Elektronik, Undang-Undang No.2 Tahun 2002 tentang Kepolisian dan Putusan Pengadilan Negeri Jakarta Utara dengan nomor putusan 1105/Pid.Sus/PN Jkt.Utr.

2) Bahan hukum sekunder berupa semua publikasi tentang hukum yang bukan merupakan dokumen-dokumen resmi. Publikasi tentang hukum meliputi buku-

\footnotetext{
10) Ibid., hal. 135-136.

11) Ibid., hal. 177.

${ }^{12)}$ Ibid., hal. 181.
} 
buku teks, kamus-kamus hukum, jurnal-jurnal hukum dan komentar-komentar atas putusan pengadilan. ${ }^{13)}$ Peneliti menyusun beberapa pertanyaan atau mengemukakan isu hukum secara tertulis, sehingga si yang diwawancarai dapat memberikan pendapatnya secara tertulis, apabila hal ini dilakukan, pendapat hukum tersebut dapat menjadi bahan hukum sekunder. ${ }^{14)}$ Maka dari itu Penulis dalam penelitian ini akan menggunakan bahan hukum sekunder berupa wawancara, dialog, kesaksian saksi ahli pengadilan, buku-buku teks, kamuskamus hukum, jurnal-jurnal hukum dan komentar-komentar atas putusan pengadilan yang bersangkutan dengan pokok pembahasan.

3) Bahan hukum tersier dapat berupa Kamus Besar Bahasa Indonesia.

\section{b. Bahan Non-Hukum}

Bahan-bahan non-hukum dapat berupa buku-buku mengenai ilmu politik, ekonomi, sosiologi, filsafat, kebudayaan ataupun laporan-laporan penelitian nonhukum dan jurnal-jurnal non hukum sepanjang mempunyai relevansi dengan topik penelitian. $^{15)}$

\section{PEMBAHASAN}

\section{A. Kasus Posisi}

Kronologi kasus pada awalnya Muhammad Faizal Tanong P alias Muhammad Faizal Tonong memiliki akun facebook atas nama Muhammad Faizal Tonong. Muhammad Faizal Tanong P bertempat tinggal di Komplek Pertamina Blok C/33 RT.003/RW.015 Kelurahan Tugu Utara Kecamatan Koja Jakarta Utara.

Pada tanggal 29 Mei 2017 Muhammad Faizal Tanong mengirimkan/memposting gambar dan tulisan pada wall/dinding akun facebook miliknya dengan tulisan antara lain: “Meski Al-Qur'an dibakar China kafir umat Islam mampu menahan diri”.

\footnotetext{
${ }^{13)}$ Ibid., hal. 181.

14) Ibid., hal. 206

${ }^{15)}$ Ibid., hal. 183-184.
} 
Pada tanggal 10 Juni 2017 Muhammad Faizal Tanong mengirimkan/memposting gambar dan tulisan pada wall/dinding akun facebook miliknya dengan kalimat antara lain: "Ngomong nasionalisme, nah loh, yang himbau umat Islam jangan ganggu politik China, siapa hanya gara-gara dapat bantuan Rp.100 juta dari Dubes RRC bikin ketawa, astagrlfirullah alhadzim".

Pada tanggal 26 Juni 2017 Muhammad Faizal Tanong mengirimkan/memposting gambar dan tulisan pada wall/dinding akun facebook miliknya dengan tulisan antara lain: "Sejak Presiden boneka RRC yang dipersiapkan oleh LBP dan Hendro dari solo itu sejak 2012”. Masih pada tanggal 26 Juni 2017 Muhammad Faizal Tanong mengirimkan/memposting tulisan berisi antara lain: "Agar orang-orang yang sebabkan si babi dipenjara harus dipenjara juga, bahwa yang dimaksud si babi adalah Ahok".

Pada tanggal 5 Juli 2017 Muhammad Faizal Tanong mengirimkan/memposting gambar dan tulisan pada wall/dinding akun facebook miliknya dengan tulisan antara lain: "Inikah Pemerintahan antek komunis RRC berkedok Pancasila itu?".

Pada tanggal 10 Juli 2017 Muhammad Faizal Tanong mengirimkan/memposting gambar dan tulisan pada wall/dinding akun facebook miliknya dengan tulisan antara lain: "Demi anak cucu, jangan sampai dijadikan anak-anak PKI dan budak-budak antek RRC”.

Pada tanggal 14 Juli 2017 Muhammad Faizal Tanong mengirimkan/memposting gambar dan tulisan pada wall/dinding akun facebook miliknya dengan tulisan antara lain: "Laurens Kevin Paliama Kristen Teroris berkalung salib membawa parang gemar membacok orang”.

Pada tanggal 17 Juli 2017 Muhammad Faizal Tanong mengirimkan/memposting gambar dan tulisan pada wall/dinding akun facebook miliknya dengan tulisan antara lain: "PKI para pembenci Islam berbaju kotak-kotak". Masih pada tanggal 17 Juli 2017 Muhammad Faizal Tanong mengirimkan/memposting gambar dan tulisan berisi antara lain: "Fakta, Said Aqil itu Kyai penipu dan doyan uang”. 


\section{B. Putusan Nomor 1105/Pid.Sus/2017/PN Jkt.Utr}

\section{Pertimbangan Majelis Hakim}

Terdakwa telah didakwa oleh Penuntut Umum dengan dakwaan yang berbentuk alternative sehingga majelis hakim dengan memperhatikan fakta-fakta hukum tersebut diatas mempertimbangkan terlebih dakwaan alternative kesatu sebagaimana diatur dalam Pasal 45 A Ayat (2) jo. Pasal 28 Ayat (2) UURI No.19 Tahun 2016 tentang Perubahan dari UURI No.11 Tahun 2008 tentang Informasi dan Transaksi Elektronik jo. Pasal 64 Ayat (1) KUHP, yang unsur-unsurnya adalah sebagai berikut:

\section{a) Setiap orang}

Unsur setiap orang adalah menunjuk pada subjek hukum person yang dapat dipertanggung jawabkan dalam hukum, yang cakap dalam hukum dan telah didakwa melakukan tindak pidana, yang di dalam perkara ini telah diajukan Muhammad Faizal Tanong P alias Faizal Muhammad Tonong dengan identitas sebagaimana telah tersebut dalam surat dakwaan, hal ini telah dibenarkan oleh terdakwa maupun penasihat hukumnya sehingga tidak terjadi error in pesona atau salah mengenai orang yang menjadi terdakwa, sedangkan untuk perbuatan materiil yang didakwakan akan dipertimbangkan dalam pertimbangan unsur-unsur berikutnya.

b) Dengan sengaja

Unsur dengan sengaja menurut Memorie van Toelichting adalah menghendaki dan mengetahui (Willens en Wetens) sedangkan menurut S.R. Sianturi dalam Asas-Asas Hukum Pidana Di Indonesia dan Penerapannya, pengertian dengan sengaja adalah dikehendaki dan diinsyafi (Willens en Wetens) menurut doktrin harus ditafsirkan secara luas, artinya mencakup ketiga gradasi kesengajaan yaitu kesengajaan sebagai maksud (Oogmerk), kesengajaan dengan kesadaran pasti atau keharusan (Opzet bij zekerheids of nood Zakelijkheids bewustzijn) dan kesengajaan dengan menyadari kemungkinan (dolus eventualis) jadi menghendaki atau yang diinsyafi pelaku, tetapi juga hal-hal yang mengarah atau berdekatan dengan kehendak atau keinsyafan itu. Bahwa unsur dengan sengaja dalam Pasal 28 Ayat (2) UU No.11 Tahun 2008 jo. 
Pasal 45 A Ayat (2) UU No.19 Tahun 2016 tentang Perubahan atas UU No.11 Tahun 2008 tentang Informasi dan Transaksi Elektronik adalah ditujukan pada perbuatan yang dilarang yaitu menyebarkan informasi yang ditujukan untuk menimbulkan rasa kebencian atau permusuhan individu dan/atau kelompok tertentu berdasarkan atas suku, agama, ras dan antargolongan (SARA).

c) Tanpa hak

Unsur tanpa hak adalah bahwa terdakwa tidak memiliki kewenangan dan tidak berhak melakukan tindakan-tindakan menyebarkan informasi yang bertujuan menimbulkan rasa kebencian atau permusuhan individu dan/atau kelompok tertentu berdasarkan atas suku, agama, ras dan antargolongan (SARA). Bahwa kewenangan untuk melakukan perbuatan yang berkaitan dengan penyampaian informasi yang terkait dengan hal-hal yang bersifat sensitive, misalnya berkaitan dengan status hukum seseorang, tidak dimiliki oleh setiap orang, hanya dimiliki orang-orang tertentu yang diatur dalam peraturan perundang-undangan.

d) Menyebarkan informasi yang ditujukan untuk menimbulkan rasa kebencian atau permusuhan individu dan/atau kelompok tertentu berdasarkan atas suku, agama, ras dan antargolongan (SARA)

Unsur ke-4 yaitu terhadap phrasa menyebarkan informasi bahwa pengertian informasi menurut Kamus Besar Bahasa Indonesia adalah penerangan, pemberitahuan, kabar atau berita tentang sesuatu. Terkait dengan makna menyebarkan informasi, dalam UU No.11 Tahun 2008 jo. UU No.19 Tahun 2016 disebutkan pengertian informasi elektronik yaitu satu atau sekumpulan data elektronik, termasuk tetapi tidak terbatas pada tulisan, suara, gambar, peta, rangcangan, foto, elektronik data interchange, surat elektronik, telegram, teleks, telecopy atau sejenisnya, huruf, tanda, angka, kode akses, symbol atau perforasi yang telah diolah yang memiliki arti atau dapat dipahami oleh orang yang mampu memahaminya sedangkan pengertian menyebarkan disamakan dengan mendistribusikan (Penjelasan Pasal 27 Ayat (1) UU No.19 Tahun 2016) yaitu 
menyebarkan kepada banyak orang, termasuk pula maksudnya adalah menyebarkan informasi dengan cara mentransmisikan dan/atau membuat dapat diaksesnya informasi elektronik dan/atau dokumen elektronik. Bahwa Pasal 5 UU No.11 Tahun 2008 tentang Informasi dan Transaksi Elektronik menyebutkan informasi elektronik dan atau dokumen elektronik dan/atau hasil cetaknya merupakan alat bukti yang sah dihubungkan dengan Berita Acara Pemeriksaan Barang Bukti Digital Nomor Barang Bukti: 91-VII-2017-CYBER tanggal 14 agustus 2017 dari Bareskrim Polri Direktorat Tindak Pidana Siber maka semua informasi dalam akun facebook terdakwa adalah merupakan alat buki.

e) Perbuatan berlanjut

Unsur sebagai satu perbuatan berlanjut adalah jika terdakwa melakukan beberapa perbuatan yang satu sama lainnya saling berhubungan sedemikian rupa sehingga dapat dipandang sebagai satu perbuatan yang diteruskan.

2. Putusan Majelis Hakim

a. Terdakwa Muhammad Faizal Tanong P Alias Faizal Muhammad Tonong telah terbukti bersalah melakukan tindak pidana tanpa hak menyebarkan informasi yang ditujukan untuk menimbulkan rasa kebencian atau permusuhan individu dan/atau kelompok masyarakat tertentu berdasarkan atas suku, agama, ras dan antargolongan (SARA);

b. Terdakwa Muhammad Faizal Tanong alias Faizal Muhammad Tonong dipidana penjara selama 1 (satu) tahun dan 6 (enam) bulan dan denda sebesar Rp.200.000.000 (dua ratus juta rupiah dengan ketentuan apabila tidak dibayar diganti dengan pidana kurungan selama 3 (tiga) bulan;

c. Masa penangkapan dan penahanan yang telah dijalani terdakwa dikurangkan seluruhnya dari pidana yang dijatuhkan;

d. Terdakwa Muhammad Faizal Tanong alias Faizal Muhammad Tonong tetap ditahan;

e. Barang bukti berupa: 
1) 1 (satu) buah KTP DKI Jakarta atas nama Muhammad Faizal Tanong P dengan NIK 3172030112720011 ;

2) 1 (satu) buah handphone Nokia Model RM-1134 warna hitam dengan SIM Card Telkomsel (AS) nomor: 085225100195;

3) 1 (satu) buah laptop Acer warna hitam (tanpa baterai) dengan serial number 71402294925 ;

Dikembalikan kepada terdakwa

4) 1 (satu) buah handphone Asus-Z010D warna hitam dengan imei 353381070249500 dan 35331070029518 beserta simcard XL 087888678101 dan simcard Axis 083129495900;

Dirampas untuk dimusnahkan

5) 1 (satu) buah akun facebook dengan nama Muhammad Tonong (Bang Izal) ID: 100011433878647 dengan urlhttps:/www.facebook.com/faizalmuhammad.bang yang diexport ke dalam bentuk CD, beserta 1 (satu) bundle print outnya;

6) 1 (satu) buah akun email dengan nama Muhammad Faizal (faizaltp33a@yahoo.com) dengan URL https:/ mg. mail. yahoo. com/neo/launch.rand=0169u0iaosr yang diexport ke dalam bentuk CD beserta 1 (satu) bundle print outnya;

7) 1 (satu) bundle screenshot/print out postingan akun media sosial facebook atas nama Faizal Muhammad Tonong dengan URL https: // www. facebook. com / faizalmuhammad.bang yang di export ke dalam sebuah CD;

Tetap terlampir dalam berkas perkara

f. Terdakwa Muhammad Faizal Tanong alias Faizal Muhammad Tonong membayar biaya perkara sejumlah Rp.5.000,00 (lima ribu rupiah).

\section{Data Hasil Wawancara}

Untuk melengkapi data hasil penelitian maka dilakukan wawancara untuk menambah bahan referensi untuk memperkuat argumentasi pada analisis melalui wawancara dengan narasumber. 


\section{Andi Hamzah ${ }^{16)}$}

Hasil wawancara berkenaan dengan pertanyaan mengenai bolehkah keterangan ahli berasal dari pihak kepolisian atau penyidik itu sendiri?, jawabannya: Tentu tidak boleh, kepolisian boleh menjadi saksi apabila polisi tersebut sebagai pembuat berita acara pemeriksaan dan terdakwa membantah berita acara pemeriksaan tersebut. Kepolisian tidak bisa atau bukan menjadi ahli harus pihak lain menjadi ahli, apabila ada keterangan ahli dari kepolisian, hakim harus tidak boleh menimbang keterangan ahli dari kepolisian tersebut. Keterangan ahli merupakan salah satu alat bukti, tidak bisa polisi memberikan alat bukti begitu pula dengan ahli forensik, ahli racun bukan merupakan alat bukti keterangan ahli apabila keterangan ahli tersebut disampaikan oleh pihak kepolisian karena polisi menjadi pihak (penyidik) akan tetapi dalam praktek banyak keterangan ahli dari ahli forensi, ahli racun yang berasal dari pihak kepolisian. Keterangan ahli harus tidak memihak apabila polisi menjadi ahli maka polisi tersebut akan memihak kepada institusi kepolisian atau kesesama penyidik. Ahli harus bebas, objektif, independent, disumpah menjadi alat bukti, dalam 184 KUHAP keterangan ahli merupakan alat bukti, bisa karena keterangan ahli, seseorang bisa dihukum maupun bisa bebas karena ahli tersebut. Polisi tidak bisa menjadi keterangan ahli karena tidak akan objektif. Keterangan ahli harus berasal dari pihak lain misalnya berasal dari Kementerian Komunikasi dan Informatika. Keterangan ahli akan diatur secara lebih lengkap di dalam RUU KUHP misalnya adanya keterangan ahli hukum yang berasal dari luar negeri. Contoh ada seorang bandar narkoba warga negara Thailand mengedarkan narkoba ke Indonesia dan ditangkap di Indonesia, maka ia bisa dikenakan dua yuridiksi hukum yang berlaku yaitu hukum Indonesia atau hukum Thailand, maka dari pihak Indonesia boleh meminta bantuan hukum keterangan ahli dari pihak Thailand.

2. Idam Wasiadi ${ }^{17)}$

\footnotetext{
16) Peneliti, Wawancara, dengan Andi Hamzah, (Jakarta: Kediaman Andi Hamzah Jakarta Selatan, 11 Mei 2018).
} 
Hasil wawancara berkenaan dengan pertanyaan mengenai bolehkah keterangan ahli berasal dari pihak kepolisian atau penyidik itu sendiri?, jawabannya: Boleh, karena di cyber crime ini mengemban 2 (dua) fungsi yakni fungsi penyidikan dan fungsi penyelidikan dan ada bantuan teknis penyidikan dan penyelidikan. Bantuan teknis ini berupa laboratorium digital forensik yang terdiri dari beberapa fungsi seperti: digital forensik umum menggunakan analysis output dan sebagainya, self phone forensic, audio video forensic (untuk mengetahui menggunakan alat apa untuk perekaman, apakah sudah di edit atau belum, bisa dicek di meta data nya, file di delete bisa di recovery, recovery password, misalnya si A punya harddisk, kemudian harddisk nya di encrypt bisa dipecahkan encrypt tersebut. Apabila si A menghancurkan handphone miliknya masih bisa di dapatkan data tersebut dengan teknologi bernama chipoff, voice analysis dan lain-lain). Keterangan ahli dari pihak kepolisian tidak akan mempengaruhi hasil penyidikan, bahwa keterangan ahli dari kepolisian bukan berasal dari penyidik sendiri melainkan lembaga-lembaga lain yang berada di institusi kepolisian misalnya dokter forensik, komputer forensik dan lainlain yang berada di kepolisian. Ahli dari pihak kepolisian akan independent tidak akan memihak kepada institusi kepolisian. Ahli dari kepolisian dipanggil dengan memenuhi syarat formil dan materiil, misalnya di sumpah terlebih dahulu, dengan menggunakan surat resmi dari pihak bareskrim tindak pidana siber (sama seperti memanggil ahli dari pihak luar). Ahli dari pihak kepolisian tidak akan subjektif melainkan akan selalu objektif dan bebas.

\section{Analisis}

Salah satu keterangan ahli yang dihadirkan dalam persidangan ialah berasal dari pihak anggota kepolisian yang dengan jabatan pemeriksa barang bukti digital pada laboratorium cyber forensik Bareskrim Polri, sebagai ahli digital forensik.

${ }^{17)}$ Peneliti, Wawancara, dengan Idam Wasiadi, (Jakarta: Kantor Bareskrim Tindak Pidana Siber Jakarta Pusat, 25 Mei 2018). 
Putusan No.1105/Pid.Sus/2017/PN Jkt.Utr di dalamnya terdapat seorang ahli yang berasal dari kepolisian, dimana ahli tersebut adalah anggota kepolisian dengan jabatan pemeriksaan barang bukti digital pada laboratorium cyber forensik Bareskrim Polri sebagai ahli digital forensik. Tugas ahli tersebut yakni melaksanakan pemeriksaan barang bukti digital yaitu terdiri dari menerima barang bukti dari penyidik dan setelah menerima barang bukti dari penyidik maka ahli tersebut melakukan serangkaian pemeriksaan terhadap barang bukti digital tersebut. Hasil analisa pemeriksaan tersebut dituangkan dalam dokumen dengan nomor barang bukti 91-VII-2017-CYBER dan Majelis Hakim pun menimbang barang bukti 91-VII-2017CYBER yang dikeluarkan oleh kepolisian.

Pembuktian adalah mencari kebenaran suatu peristiwa hukum. Peristiwa hukum adalah peristiwa yang mempunyai akibat hukum. ${ }^{18)}$ Sedangkan hukum pembuktian adalah ketentuan-ketentuan mengenai pembuktian yang meliputi alat bukti, barang bukti, cara mengumpulkan dan memperoleh bukti sampai pada penyampaian bukti di pengadilan serta kekuatan pembuktian dan beban pembuktian dalam perkara pidana. $^{19)}$

Pembuktian adalah perbuatan membuktikan bahwa benar suatu peristiwa pidana telah terjadi dan terdakwalah yang bersalah melakukannya, sehingga harus mempertanggungjawabkannya. ${ }^{20)}$ Pembuktian merupakan masalah yang memegang peranan dalam proses pemeriksaan sidang pengadilan. Melalui pembuktian ditentukan nasib terdakwa. Apabila hasil pembuktian dengan alat-alat bukti ditentukan undang-undang tidak cukup membuktikan kesalahan yang didakwakan kepada terdakwa, terdakwa dibebaskan dari hukuman, sebaliknya kalau kesalahan terdakwa dapat dibuktikan dengan alat-alat bukti yang disebut dalam Pasal 184 KUHAP, terdakwa dinyatakan bersalah. Kepadanya akan dijatuhkan hukuman. ${ }^{21)}$

\footnotetext{
${ }^{18)}$ Eddy, Op.Cit., hal. 7.

19) Ibid., hal. 5.

${ }^{20)}$ Andi, Op.Cit., hal. 230.

${ }^{21)}$ M. Yahya Harahap, Op.Cit., hal. 273.
} 
Alat bukti dalam KUHAP diatur dalam Pasal 184 KUHAP dengan alat bukti sebagai berikut:

1) Keterangan saksi;

2) Keterangan ahli;

3) Surat;

4) Petunjuk;

5) Keterangan terdakwa.

Pasal 1 angka 28 KUHAP menyatakan bahwa keterangan ahli adalah keterangan yang diberikan oleh seorang yang memiliki keahlian khusus tentang hal yang diperlukan untuk membuat terang suatu perkara pidana guna kepentingan pemeriksaan, sedangkan dalam Pasal 186 KUHAP keterangan ahli ialah apa yang seorang ahli nyatakan di sidang pengadilan.

Pasal 160 Ayat (4) KUHAP menyatakan bahwa jika pengadilan menganggap perlu, seorang saksi atau ahli wajib bersumpah atau berjanji sesudah saksi atau ahli itu selesai memberi keterangan, sedangkan dalam Pasal 179 KUHAP menyatakan Ayat (1) "Setiap orang yang diminta pendapatnya sebagai ahli kedokteran kehakiman atau dokter atau ahli lainya wajib memberikan keterangan ahli demi keadilan, Ayat (2) "Semua ketentuan tersebut di atas untuk saksi berlaku juga sebagai mereka yang memberikan keterangan ahli, dengan ketentuan bahwa mereka mengucapkan sumpah atau janji akan memberikan keterangan yang sebaik-baiknya dan yang sebenarnya menurut pengetahuan dalam bidang keahliannya".

Penyelidik dalam Pasal 1 butir 4 KUHAP ialah pejabat polisi negara Republik Indonesia yang diberi wewenang oleh undang-undang ini untuk melakukan penyelidikan. Penyelidik dalam Pasal 4 KUHAP mengartikan penyelidik adalah setiap pejabat polisi Republik Indonesia sehingga mempunyai tugas dan wewenang yang terdapat dalam Pasal 5 KUHAP yaitu:

1. Penyelidik sebagaimana dimaksud dalam pasal 4:

a. Karena kewajiban mempunyai wewenang: 
1) Menerima laporan atau pengaduan dari seorang adanya tindak pidana;

2) Mencari keterangan dan barang bukti;

3) Menyuruh berhenti seorang yang dicurigai dan menanyakan serta memeriksa tanda pengenal diri;

4) Mengadakan tindakan lain menurut hukum yang bertanggungjawab.

b. Atas perintah penyidik dapat melakukan tindakan berupa:

1) Penangkapan, larangan meninggalkan tempat, penggeledahan dan penyitaan;

2) Pemeriksaan dan penyitaan surat;

3) Mengambil sidik jari dan memotret seorang;

4) Membawa dan menghadapkan seorang kepada penyidik.

2. Penyelidik membuat dan menyampaikan laporan hasil pelaksanaan tindakan sebagaimana tersebut pada ayat (1) kepada penyidik.

Penyidik dalam Pasal 1 angka 1 KUHAP jo. Pasal 1 angka 10 UndangUndang No.2 Tahun 2002 tentang Kepolisian Negara RI, bahwa yang dimaksud penyidik adalah pejabat polisi negara republik Indonesia atau pejabat pegawai negeri sipil tertentu yang diberi wewenang khusus oleh undang-undang untuk melakukan penyidikan.

Kewenangan penyidik dalam Pasal 7 Ayat (1) KUHAP diberikan kewenangan melaksanakan kewajibannya yaitu antara lain:

1. menerima laporan atau pengaduan dari seorang tentang adanya tindak pidana;

2. melakukan tindakan pertama pada saat di tempat kejadian;

3. menyuruh berhenti seorang tersangka dan memeriksa tanda pengenal dari tersangka;

4. melakukan penangkapan, penahanan, penggeledahan, dan penyitaan;

5. melakukan pemeriksaan dan penyitaan surat; 
6. mengambil sidik jari dan memotret seorang;

7. memanggil orang untuk didengar dan diperiksa sebagai tersangka atau saksi;

8. mendatangkan orang ahli yang diperlukan dalam hubungannya dengan pemeriksaan perkara;

9. mengadakan penghentian penyidikan;

10. mengadakan tindakan lain menurut hukum yang bertanggung jawab.

Pembuktian yang meliputi alat bukti, barang bukti, cara mengumpulkan dan memperoleh bukti sampai pada penyampaian bukti di pengadilan serta kekuatan pembuktian dan beban pembuktian dalam perkara pidana.

Salah satu alat bukti pada KUHAP yaitu keterangan ahli yang memiliki peran penting dalam sistem pembuktian pidana yang akan menentukan apakah terdakwa bersalah atau tidak walaupun kekuatan alat bukti keterangan ahli bersifat bebas, yang artinya sangat bergantung pada hakim akan tetapi peran alat bukti keterangan ahli dalam praktik pengadilan sangat penting dalam pembuktian pidana.

Seorang ahli dalam memberikan keterangan ahlinya harus demi keadilan seperti yang dinyatakan dalam Pasal 179 Ayat (1) KUHAP, jadi ahli harus adil dalam memberikan keterangannya tidak boleh ada intervensi dari pihak lain, seorang ahli harus bebas, objektif dan independent, sedangkan pada Pasal 1 angka 28 ada kalimat "keahlian khusus" yang dimana didalam KUHAP maupun peraturan pelaksananya tidak ada penjelasan mengenai apa yang dimaksud keahlian khusus, namun dalam praktik peradilan pidana keahlian khusus ini bisa ditunjukkan dari pengalaman dan/atau pengetahuan sang ahli atas bidang tertentu.

Ahli yang dihadirkan di persidangan umumnya adalah ahli yang telah dimintai keterangan oleh penyidik dalam proses penyidikan. Dalam perkara pidana pembunuhan, misalnya, ahli yang dihadirkan seringkali dokter forensik yang juga bekerja di rumah sakit Polri. Apakah dalam konteks itu terjadi 
konflik kepentingan, sehingga ahli akan selalu membela kepentingan penyidik? Menurut Lucky Raspati, konflik kepentingan merupakan sesuatu yang pasti terjadi sejak awal. Namun hal tersebut sebenarnya juga dibatasi, sebatas ahli mengabdi kepada kepentingan ilmu pengetahuan dan pertanggungjawaban kepada ilmu pengetahuan. "Bukan kepada para pihak (kepentingan)," kata Lucky kepada hukumonline, Senin (22/8). Menurut dia, kekeliruan yang sering terjadi dalam proses peradilan di Indonesia adalah keterangan ahli yang dihadirkan oleh para pihak lebih bertujuan untuk kepentingan para pihak. Ilmu pengetahuan dan hakikat 'keadilan' yang disebut Pasal 179 ayat (1) KUHP seolah terabaikan. ${ }^{22)}$

Lucky mengatakan bahwa ahli dalam suatu kasus pidana memang harus dilibatkan sejak awal karena tugasnya untuk menganalisis sesuai bidang keilmuan. Hasil analisis berupa opini dituangkan dalam BAP, dan kemudian BAP masuk ke persidangan. Ahli tersebut boleh memberikan keterangan dalam persidangan untuk membantu hakim memahami, misalnya,penyebab kematian seseorang. Sayangnya, lanjut Lucky, Indonesia tidak memiliki kriteria ahli yang bisa masuk ke persidangan. Terkesan siapa saja bisa menjadi ahli. Bahkan sarjana hukum bisa menjadi ahli untuk menerangkan suatu peraturan, padahal ada prinsip 'hakim dianggap tahu hukum' (ius curia novit). Hakim juga khawatir berimbas pada pelaporan ke Komisi Yudisial jika menolak ahli yang dihadirkan salah satu pihak. ${ }^{23)}$

Berdasarkan hasil wawancara dengan Andi Hamzah bahwa keterangan ahli tidak boleh berasal dari kepolisian dikarenakan keterangan ahli harus bebas, objektif dan independet, apabila dari pihak kepolisian menjadi keterangan ahli maka polisi yang menjadi ahli tersebut tidak akan bisa bebas, objektif dan independent karena akan terpengaruh oleh institusi kepolisian

${ }^{22)}$ Anonim, "Kedudukan Ahli dan Pendapatnya dalam Perkara Pidana", www.hukumonline.com, 23 Mei 2018, hal. 1.

${ }^{23)}$ Ibid., hal. 1. 
tersebut dan akan membenarkan hasil penyidikan yang dilakukan oleh sesama pihak kepolisian.

Berdasarkan definisi pembuktian bahwa pembuktian merupakan inti sari dari suatu proses peradilan pidana yang akan menentukan apakah seorang terdakwa bersalah atau tidak, tujuan utama pembuktian adalah mencari kebenaran materiil bukan kebenaran formil.

Pembuktian yang meliputi alat bukti, barang bukti, cara mengumpulkan dan memperoleh bukti sampai pada penyampaian bukti di pengadilan serta kekuatan pembuktian dan beban pembuktian dalam perkara pidana.

Salah satu alat bukti pada KUHAP yaitu keterangan ahli yang memiliki peran penting dalam sistem pembuktian pidana yang akan menentukan apakah terdakwa bersalah atau tidak walaupun kekuatan alat bukti keterangan ahli bersifat bebas, yang artinya sangat bergantung pada hakim akan tetapi peran alat bukti keterangan ahli dalam praktik pengadilan sangat penting dalam pembuktian pidana.

Seorang ahli dalam memberikan keterangan ahlinya harus demi keadilan seperti yang dinyatakan dalam Pasal 179 Ayat (1) KUHAP, jadi ahli harus adil dalam memberikan keterangannya tidak boleh ada intervensi dari pihak lain, seorang ahli harus bebas, objektif dan independent, sedangkan pada Pasal 1 angka 28 ada kalimat "keahlian khusus" yang dimana didalam KUHAP maupun peraturan pelaksananya tidak ada penjelasan mengenai apa yang dimaksud keahlian khusus, namun dalam praktik peradilan pidana keahlian khusus ini bisa ditunjukkan dari pengalaman dan/atau pengetahuan sang ahli atas bidang tertentu.

Jika melihat pada tugas dan wewenang kepolisian yang salah satunya ialah melakukan pemeriksaan serta mengumpulkan barang bukti dan tujuan utama pembuktian ialah membuktikan apakah terdakwa bersalah atau tidak serta begitu pentingnya keterangan ahli dalam sistem peradilan pidana, maka tidak mungkin ahli dari kepolisian bisa menjadi keterangan ahli dalam 
peradilan pidana dan tidak mungkin menjadi pertimbangan majelis hakim dikarenakan keterangan ahli dari ahli kepolisian tidak akan bisa bebas, objektif dan independent, mengingat bahwa keterangan ahli dari kepolisian itu sendiri akan memihak institusi tempat ahli tersebut bekerja dan selalu membenarkan hasil pemeriksaan kepolisian (akan sangat subjektif). Ahli dari kepolisian akan selalu terikat oleh institusi kepolisian.

Pertimbangan Majelis Hakim dalam menimbang keterangan ahli dari pihak penyidik menjadikan tujuan utama pembuktian tidak berjalan sebagaimana mestinya dan sangat merugikan pihak terdakwa karena ahli dari pihak penyidik akan selalu membenarkan hasil penyidik itu sendiri tanpa benar-benar memberikan keterangan ahli sesuai keahliannya sehingga kebebasan dan independensi ahli menjadi tidak berjalan sebagaimana mestinya.

\section{PENUTUP}

\section{A. Kesimpulan}

Berdasarkan uraian analisis di atas, maka dapat ditarik kesimpulan sebagai berikut:

Ahli dari kepolisian adalah ahli yang tidak bebas dan independent karena terikat oleh institusi tempat ahli tersebut bekerja yakini institusi kepolisian. Keterangan ahli dari pihak kepolisian tidak diperbolehkan karena dalam Pasal 1 angka 28 KUHAP keterangan ahli membuat terang suatu perkara pidana guna kepentingan pemeriksaan dan pihak kepolisian sendiri yang mempunyai tugas dan wewenang untuk melakukan pemeriksaan sehingga akan sangat tidak independent. Sedangkan Pasal 179 Ayat (1) KUHAP bahwa ahli memberikan keterangan ahli demi keadilan sehingga apabila keterangan ahli dari pihak kepolisian tidak akan adil dan akan sangat subjektif memihak pihak kepolisian itu sendiri. Walaupun dalam KUHAP tidak mengatur secara khusus apakah ahli dari kepolisian bisa jadi seorang ahli dan didengar keterangan ahli nya tersebut akan tetapi sangat tidak mungkin dan tidak logis bahwa 
keterangan ahli berasal dari pihak kepolisian walaupun ahli polisi tersebut tidak berhubungan langsung dengan penyidikan dan penyelidikan tetapi keterangan ahli dari pihak kepolisian dinilai akan sangat subjetif, tidak akan objektif dan memihak institusi tempat ahli tersebut bekerja.

\section{B. Saran}

Berdasarkan kesimpulan di atas, maka saran yang dapat diberikan adalah sebagai berikut:

Kepada perancang RUU KUHP dan KUHAP yakni badan legislatif negara (Dewan Perwakilan Rakyat) harus jelas dan tegas dalam mendefinisikan ahli yang dimaksud sehingga tidak terjadi kesalahan dalam penggunaan keterangan ahli dalam praktek hukum pidana di Indonesia dan RUU KUHP dan KUHAP yang masih dalam pembahasan di DPR diharapkan segera disahkan menjadi Undang-Undang yang cukup lengkap dan jelas yang bisa memberikan pedoman bagi praktisi hukum peradilan pidana di Indonesia dalam menghadirkan ahli dan keterangan ahli yang dapat didengarkan dan yang bisa menjadi pertimbangan majelis hakim serta kebebasan dan independensi keterangan ahli dari seorang ahli selalu ada dan terjaga dengan baik.

Keterangan ahli dalam KUHAP harus dilakukan revisi yang mengatur keterangan ahli secara khusus dan lengkap terhadap masalah-masalah yang terjadi di dalam praktek peradilan pidana. Keterangan ahli dalam KUHAP harus mengatur apakah keterangan ahli dari suatu institusi diperbolehkan khususnya institusi kepolisian yang banyak menjadi ahli dari pihak internal kepolisian itu sendiri di pengadilan. RUU KUHP dan KUHAP diharapkan dapat menyelesaikan masalah keterangan ahli dari suatu institusi ini dan memperjelas syarat-syarat seorang ahli dan keterangan ahli yang dapat didengarkan dalam sidang pengadilan.

Kepada Majelis Hakim diharapkan lebih teliti dalam menentukan keterangan ahli mana yang harus didengarkan dan dipertimbangkan sehingga keterangan ahli dari pihak internal yang tidak memenuhi syarat keterangan ahli tidak masuk dalam 
pertimbangan majelis hakim karena keterangan ahli dari pihak penyidik akan sangat tidak bebas dan independent serta akan selalu membenarkan hasil penelitian dari pihak penyidik itu sendiri dan akan sangat merugikan sistem pembuktian pidana di Indonesia serta merugikan terdakwa itu sendiri.

\section{DAFTAR PUSTAKA}

Ali, Achmad. Menguak Tabir Hukum. Jakarta: PT Ghalia Indonesia, 2008.

Anonim. "Kedudukan Ahli dan Pendapatnya dalam Perkara Pidana", www.hukumonline.com, 23 Mei 2018.

Harahap, M. Yahya. Pembahasan Permasalahan dan Penerapan KUHAP: Penyidikan dan Penuntutan. Jakarta: Sinar Grafika, 2010.

Hiariej, Eddy O.S. Teori \& Hukum Pembuktian. Jakarta: Penerbit Erlangga, 2012.

Ilyas, Amir. Asas-Asas Hukum Pidana. Yogyakarta: Rangkang Education Yogyakarta \& Pu-Kap Indonesia, 2012.

Indonesia. Putusan Pengadilan Negeri Jakarta Utara No.1105/Pid.Sus/2017/PN Jkt.Utr. . Undang-Undang Dasar Negara Republik Indonesia Tahun 1945. - Undang-Undang Nomor 8 Tahun 1981 tentang Hukum Acara Pidana (Lembaran Negara Republik Indonesia Tahun 1981 Nomor 76, Tambahan Lembaran Negara Republik Indonesia Nomor 3258).

. Undang-Undang Nomor 2 Tahun 2002 tentang Kepolisian Negara Republik Indonesia (Lembaran Negara Republik Indonesia Tahun 2002 Nomor 2, Tambahan Lembaran Negara Republik Indonesia Nomor 4168). 
. Undang-Undang Nomor 11 Tahun 2008 tentang Informasi dan Transaksi Elektronik (Lembaran Negara Republik Indonesia Tahun 2008 Nomor 58, Tambahan Lembaran Negara Republik Indonesia Nomor 4843).

. Undang-Undang Nomor 40 Tahun 2008 tentang Penghapusan Diskriminasi Ras dan Etnis (Lembaran Negara Republik Indonesia Tahun 2008 Nomor 170, Tambahan Lembaran Negara Republik Indonesia Nomor 4919).

. Undang-Undang Nomor 19 Tahun 2016 tentang Perubahan Atas UndangUndang Nomor 11 Tahun 2008 tentang Informasi dan Transaksi Elektronik (Lembaran Negara Republik Indonesia Tahun 2008 Nomor 58, Tambahan Lembaran Negara Republik Indonesia Nomor 5952).

Marzuki, Peter Mahmud. Penelitian Hukum, Edisi Revisi. Jakarta: Kencana Prenadamedia Group, 2009.

Penelitian Hukum. Cetakan ke-7. Jakarta: Kencana Prenada Media Group, 2011.

Sitompul, Joshua. "Pasal Untuk Menjerat Penyebar Kebencian SARA Di Jejaring Sosial”, www.hukumonline.com, 16 Januari 2018.

Sofyan, Andi dan H. Abd. Asis. Hukum Acara Pidana Suatu Pengantar, Jakarta: Prenadamedia Group, 2014. 